\title{
Genotoxicity assessment of cadmium chloride in Labeo rohita (Hamilton, 1822) based on induction of micronuclei and other nuclear abnormalities
}

\author{
RAJINDER JINDAL AND SAKSHI VERMA \\ Aquatic Biology Laboratory, Panjab University, Chandigarh - 160 014, Panjab, India \\ e-mail:sakshi.aquas@gmail.com
}

\begin{abstract}
The genotoxic potential of environmentally realistic concentrations of cadmium chloride $\left(\mathrm{CdCl}_{2}\right)$ was assessed in vivo using micronucleus assay on gill epithelial cells, erythrocytes of peripheral blood and cephalic kidney of Labeo rohita. Fish were exposed to two different concentrations $\left(0.37\right.$ and $\left.0.62 \mathrm{mg} \mathrm{l}^{-1}\right)$ of $\mathrm{CdCl}_{2}$ for 24, 48, 72 and $96 \mathrm{~h}$. In addition to micronuclei $(\mathrm{MN})$, other nuclear abnormalities (NA) such as induction of nuclear bud (NBu) and fragmented-apoptotic (FA) cells were also evaluated for assessment of cytotoxicity of $\mathrm{CdCl}_{2}$. $\mathrm{MN}$ and $\mathrm{NA}$ frequencies in all the observed tissues were high in fish exposed to both the concentrations as compared to control. The frequency of MN was highest in the gill cells followed by erythrocytes of peripheral blood and cephalic kidney in fish treated with both the toxicant concentrations. However, the higher concentration of $\mathrm{CdCl}_{2}$ caused significant $(\mathrm{p}<0.05)$ induction of $\mathrm{MN}$ after $48 \mathrm{~h}$, while the lower concentration caused marked induction after $96 \mathrm{~h}$ of acute exposure. A concentration and time dependent elevation in MN and other NA frequency was noticed in all the three types of tissues tested. A three-fold increase in the occurrence of MN was observed in gill cells of the fish treated with $\mathrm{CdCl}_{2}$ at higher concentration as compared to that of lower concentration.
\end{abstract}

Keywords: Cadmium chloride, Genotoxicity, Labeo rohita, Micronuclei, Nuclear abnormalities

Fish act as sentinel organisms for indicating the dispersal and impact of genotoxic agents in the aquatic environment (Yadav and Trivedi, 2009). Fish can be employed to scrutinise the chemicals which are likely to cause teratogenic and carcinogenic effects in humans since they generally respond similar to higher vertebrates (Al-Sabti and Metcalfe, 1995). The micronucleus test has proved to be simple, reliable and useful method for analysing the genotoxic potential of contaminants encountered in water bodies. The micronuclei $(\mathrm{MN})$ are formed when a whole chromosome or chromosomal fragment lags behind during cell division due to lack or damage of centromeres or dysfunction of mitotic spindle (Vincent-Hubert et al., 2011). The analysis of other nuclear abnormalities including formation of nuclear buds (NBu) and fragmented-apoptotic (FA) cells along with micronuclei have also been found to be a valuable tool in evaluating the cyto-genotoxic effects of pollutants (Anbumani and Mohankumar, 2012).

$\mathrm{MN}$ can be analysed in various types of cells like erythrocytes, gill, kidney, liver and fin cells (Bolognesi et al., 2006). In our study, gill cells, erythrocytes of peripheral blood and cephalic kidney were selected because gills and peripheral erythrocytes represent the first organs to be in direct contact with pollutants present in water while cephalic kidney is mainly responsible for haemopoiesis, where cells divide extensively (Rybakovas et al., 2009). In addition, erythrocytes easily provide thousands of scorable cells with large nucleus (MacGregor et al., 1980).
Heavy metal pollution, as a consequence of increasing urbanisation and industrialisation, poses a potential threat to aquatic ecosystems and human health due to their toxicity and biomagnification ability (Atli and Canli, 2008). Among them, cadmium $(\mathrm{Cd})$, one of the most deleterious environmental pollutants, is classified as a human carcinogen (IARC, 1993). It is related to a wide spectrum of anthropogenic activities such as zinc, copper and lead mining, coal utilisation and tobacco smoking; and products such as plastics, phosphate fertilisers, nickel-cadmium batteries (Gad, 2014). The genotoxicity of $\mathrm{Cd}$ is reported in part to be indirectly mediated via production of oxidative stress and interference with several DNA-repair mechanisms (Waisberg et al., 2003). Considering the above, this study was performed to analyse the genotoxic potential of $\mathrm{CdCl}_{2}$ on Labeo rohita (Hamilton, 1822), acutely exposed to relatively low and environmentally realistic concentrations (0.37 and $0.67 \mathrm{mg} \mathrm{l}^{-1}$ ) of $\mathrm{CdCl}_{2}$. L. rohita, an Indian major carp, is a commercially important, easily culturable species which has high growth potential. The genotoxic effects of acute exposure of $L$. rohita to these concentrations are not well studied. The objectives of our study were to evaluate the frequency of occurrence of micronuclei $(\mathrm{MN})$ and other nuclear abnormalities (NA) in the gill cells, erythrocytes of peripheral blood and cephalic kidney in L. rohita exposed to $\mathrm{CdCl}_{2}$ as well as to compare the sensitivity of the three tissues towards the toxicant. 
For the experiment, technical-grade $\mathrm{CdCl}_{2}$ (anhydrous) was purchased from Sigma-Aldrich. Two concentrations of $\mathrm{CdCl}_{2}$ i.e. 0.37 and $0.62 \mathrm{mg} \mathrm{l}^{-1}$, were used based on the concentrations of $\mathrm{Cd}$ reported in aquatic environment such as $0.68 \mathrm{mg} \mathrm{l}^{-1}$ in Malta River, $0.59 \mathrm{mg} \mathrm{l}^{-1}$ in Hooghly River and $0.47 \mathrm{mg} \mathrm{l}^{-1}$ in Subernarekha River, West Bengal (COMAPS, 1990-1999). Live healthy specimens of L. rohita $(18.05 \pm 0.98 \mathrm{~g}, 12.05 \pm 0.19 \mathrm{~cm})$, obtained from Sultan Fish Seed Farm, Haryana, India, were acclimatised to laboratory conditions for 15 days in glass aquaria (300 1 capacity) filled with dechlorinated water. The fish were fed twice a day with commercially available feed (crude protein-28\%, crude fiber- $4 \%$, crude fat-3\% and moisture- $10 \%$ ). The aquaria were provided with undergravel filters and aeration was maintained using aerators.

In the semi-static bioassay, the acclimatised fish were allocated into three groups and shifted to plastic (Sintex) tanks with 401 capacity. Control fish were kept in dechlorinated water and considered as group I; while fish of group II and III were exposed to nominal concentrations of 0.37 and $0.62 \mathrm{mg} \mathrm{l}^{-1}$ of $\mathrm{CdCl}_{2}$ in water, respectively. Fish were not fed during the experiment and the test water was renewed every day with water, containing same $\mathrm{CdCl}_{2}$ concentration, to avoid variation due to presence of fish metabolites. The test water was analysed every $24 \mathrm{~h}$ with Inductively Coupled Argon Plasma Atomic Emission Spectroscopy (Thermo Electron Corporation, iCAP 6000 series) to maintain $\mathrm{Cd}$ concentration in the experimental tanks. The mean measured concentrations of Cd were $0.23 \pm 0.008$ and $0.38 \pm 0.01 \mathrm{mg} \mathrm{l}^{-1}$ for nominal concentrations of 0.37 and $0.62 \mathrm{mg} \mathrm{l}^{-1}$ of $\mathrm{CdCl}_{2}$, respectively. Experiment was performed in triplicates. For the $\mathrm{MN}$ and NA analysis, samples of gills, peripheral blood and cephalic kidney of the experimental anumals were collected at $24,48,72$ and $96 \mathrm{~h}$ of $\mathrm{CdCl}_{2}$ exposure.

Thin smears of peripheral blood, obtained from the caudal peduncle with the help of heparinised syringe, were prepared on pre cleaned glass slides and fixed with methanol (10 min). Fixed smears were then air dried and stained with $6 \%$ Giemsa (20 min) (Jindal and Verma, 2015). Afterwards fish were sacrificed by cervical dislocation following the guidelines of the Institutional Animal Ethics Committee of Panjab University, Chandigarh, IAEC/527. Kidney was dissected out, carefully separating a small piece of cephalic kidney and dragged on clean glass slides. After air drying, the smears were fixed in methanol $(10 \mathrm{~min})$ and then stained with $10 \%$ Giemsa solution (Barsiene et al., 2005). Gill arches were taken out and processed according to Barsiene et al. (2008). Briefly, gill arches were kept in Carnoy's fixative (3:1 methanol: acetic acid) for 2-3 min. Carnoy's fixative is used to preserve nucleic acids and fix tissue through hydrogen bonding (Howat and Wilson, 2014). The epithelial cells were scraped off the gill arches and the cell suspension was used to prepare smears. Air dried smear were fixed with methanol (10 min) followed by staining with Giemsa solution (4\%). Further, three fish were sacrificed from each tank ( 9 fish per group) at each sampling time and five slides (per fish) were prepared per tissue. Two hundred cells from each slide were randomly scored using light microscope (Olympus Magnus MLXi; camera, Jenoptik, Germany). MN and other NA frequencies were presented as the number of MN/NA per 1000 cells scored.

For statistical analysis SPSS 18.0 software was used and data was confirmed for normal distribution using Kolmogorov-Smirnov test. One way analysis of variance (ANOVA) was applied to compare the outcomes from different groups, followed by Tukey's post hoc test, $(p<0.05)$.

Micronuclei were determined as circular or ovoid shaped chromatin body, with a diameter less than one-third of the main nucleus (Fig. 1a), having staining pattern similar to that of the main nucleus and clearly detached from it (Figs. 1b, e). Results of MN analysis in epithelial cells of gills, erythrocytes of peripheral blood and cephalic kidney of control and the fish exposed to $\mathrm{CdCl}_{2}$ are summarised in Fig. 2(a), (b) and (c). The MN frequency in all the three tissues of control group remained almost constant. However, MN frequencies showed significant $(\mathrm{p}<0.05)$ induction in both the metal treated groups as compared to control. $\mathrm{MN}$ frequencies increased in the tissues in a concentration and time dependent manner. MN assay has also been applied by Cavas et al. (2005) in three different fish species i.e. Corydoras paleatus, Carassius gibelio and Cyprinus carpio and noticed the potential of $\mathrm{Cd}$ to cause genotoxicity. Vincent-Hubert et al. (2011) reported similar findings in gill cells and haemocytes of Dreissena polymorpha treated with $\mathrm{Cd}$. Variability analysis of $\mathrm{MN}$, elucidated that exposure to higher concentration of $\mathrm{CdCl}_{2}\left(0.62 \mathrm{mg} \mathrm{l}^{-1}\right)$ induced $\mathrm{MN}$ frequency 3-times higher than that observed at $0.37 \mathrm{mg} \mathrm{l}^{-1}$ of exposure. The maximum $\mathrm{MN}$ frequency was detected after $96 \mathrm{~h}$ of exposure to $0.62 \mathrm{mg} \mathrm{l}^{-1}$ of $\mathrm{CdCl}_{2}$, in the gill cells of $L$. rohita. Considerable $(p<0.05)$ induction of MN was encountered in erythrocytes of cephalic kidney of fish exposed to $0.62 \mathrm{mg} \mathrm{l}^{-1}$ of $\mathrm{CdCl}_{2}$ at 48,72 and $96 \mathrm{~h}$ of exposure period, while $0.37 \mathrm{mg} \mathrm{l}^{-1}$ of $\mathrm{CdCl}_{2}$ notably induced $\mathrm{MN}$ frequency only at $96 \mathrm{~h}$ post-exposure. In case of erythrocytes of peripheral blood, significant $(\mathrm{p}<0.05)$ frequencies of $\mathrm{MN}$ were observed after $72 \mathrm{~h}$ exposure period.

By comparing $\mathrm{MN}$ assay data, it was found that gill epithelial cells exhibited higher $\mathrm{MN}$ frequencies than erythrocytes. The results obtained from the present study corroborated the observations of Cavas and Ergene-Gozukara (2003) and Cavas et al. (2005) that the gill cells seems to be more sensitive to $\mathrm{CdCl}_{2}$ when compared to erythrocytes. These findings are also substantiated by Manna and Sadhukhan (1986) who reported higher sensitivity of gills cells of Oreochromis mossambicus towards the genotoxic 
exposure in comparison to other tissues including liver and kidney. Kaur and Dua (2016) found gill cells of L. rohita to be more responsive to $\mathrm{MN}$ assay and other nuclear abnormalities assay than erythrocytes and suggested their use as biomarkers of cytotoxicity. This difference in occurrence of MN between the tissues could be as a result of differences in the kinetics of cell proliferation. Additionally, damaged erythrocytes tend to be eliminated rapidly as compared to intact erythrocytes (Al-Sabti and Metcalfe, 1995; Barsiene et al., 2006). Another possible reason may be the direct contact of gill cells to contaminants in the ambient aquatic environment (Cavas and Ergene-Gozukara, 2003).

Nuclear bud and fragmented-apoptotic cells were determined following the criteria of Fenech et al. (2003). Briefly, fragmented-apoptotic cells show fragmentation of nucleus into smaller nuclear bodies within an intact cytoplasm (Figs. 1c, 1f), whereas, nuclear buds are morphologically similar to MN, but are attached to the main nucleus through a narrow stalk of nucleoplasmic material (Fig. 1d, 1g).

Fig. 2(d-f) and Fig. 2(g-i) illustrate the results obtained from analysis of $\mathrm{NBu}$ and $\mathrm{FA}$ frequencies, respectively in the three tissues of control and exposed fish. Exposure to $0.62 \mathrm{mg} \mathrm{l}^{-1}$ of $\mathrm{CdCl}_{2}$ caused significant $(\mathrm{p}<0.05)$ induction of $\mathrm{NBu}$ and FA cells in the gill cells at all the exposure periods, except $24 \mathrm{~h}$. However, $0.37 \mathrm{mg} \mathrm{l}^{-1}$ of $\mathrm{CdCl}_{2}$ exposure caused marked induction of NA only at $96 \mathrm{~h}$ post-exposure.

Similar to MN frequencies, concentration and duration dependent increased frequencies of NA were observed. These results are concordant with those observed by Ozkan et al. (2011) and Vignardi et al. (2015). Similar elevation in

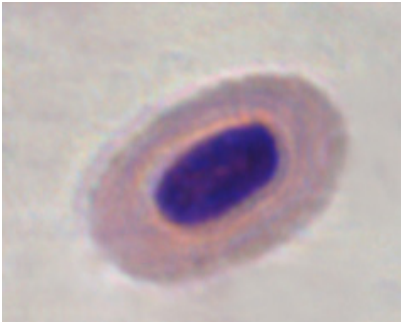

(a)

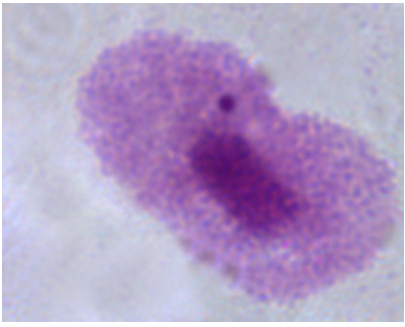

(e)

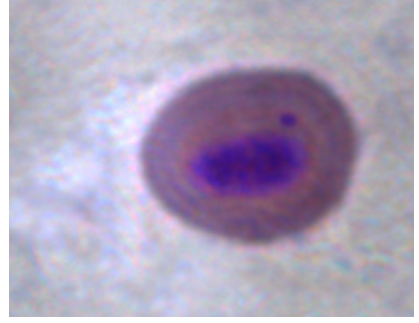

(b) the NA has also been encountered in different fish species exposed to gamma radiations (Anbumani and Mohankumar, 2012) and crude oil (Barsiene et al., 2006). In spite of numerous studies on induction of nuclear abnormalities in aquatic organisms treated with various chemicals under field or laboratory conditions, the complete understanding of mechanisms underlying their formation is lacking. Anbumani and Mohankumar (2012) proposed that acute exposure to pollutants may induce formation of FA cells which involve complex cascade of events such as condensation of chromatin, fragmentation and cell shrinkage. Nuclear bud formation may be a way adapted by the cell to eradicate the amplified DNA (Shimizu et al., 1998) or DNA fragments that have been improperly condensed (Shimizu et al., 2000).

In our study, the peripheral erythrocytes and cephalic kidney of the exposed fish exhibited marked induction in frequencies of $\mathrm{NBu}$. Nonetheless, frequency of FA cells was very low in the erythrocytes of peripheral blood of L. rohita exposed to both the concentrations. It has been proposed that erythrocytes in fish rarely show apoptosis and rather show macrophage-dependent removal of erythrocytes (Holcik, 2002).

Our study clearly demonstrated the induction of $\mathrm{MN}$ in fish after short term exposure to environmentally relevant concentrations of $\mathrm{CdCl}_{2}$ and thus, suggests its genotoxic potential. Formation of nuclear bud and fragmented-apoptotic cells following exposure to the heavy metal also indicated its cytotoxicity. L. rohita appeared to be a good test organism for use in monitoring the genotoxicity of pollutants in aquatic environment. Furthermore, from the results obtained in the present study, gill cells seem to be more sensitive to

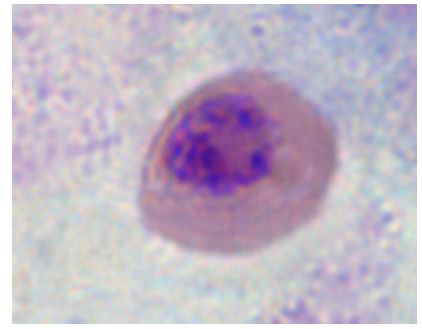

(c)

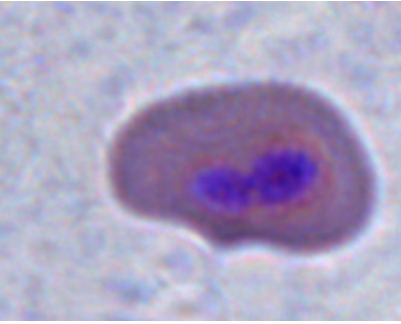

(d)

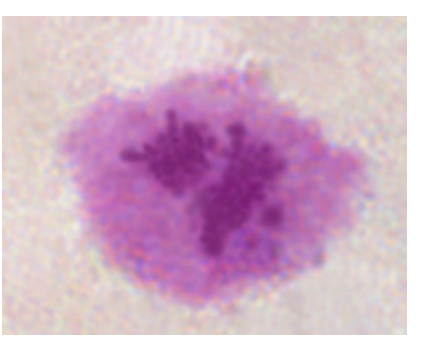

(f)

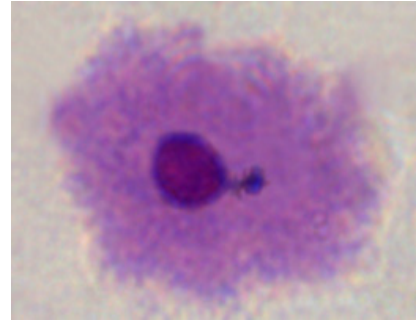

(g)
Fig. 1. Erythrocytes with (a) normal nucleus, (b) micronucleus, (c) fragmented-apoptotic cells, (d) nuclear bud (NBu); and gill cells with (e) micronucleus, (f) fragmented-apoptotic cells, (g) nuclear bud (NBu). (Giemsa, 1000×) 


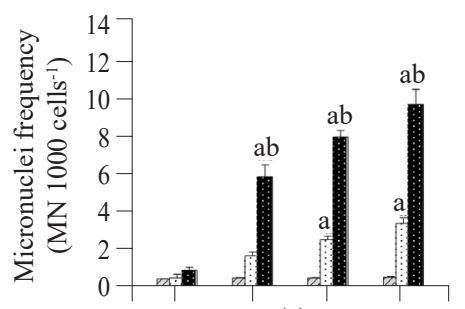

(a)

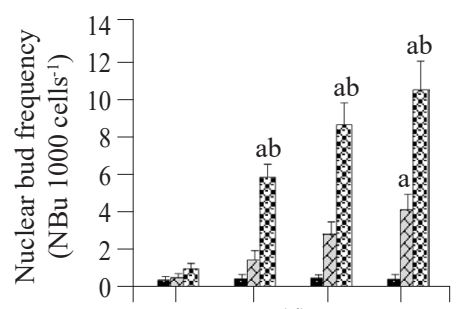

(d)

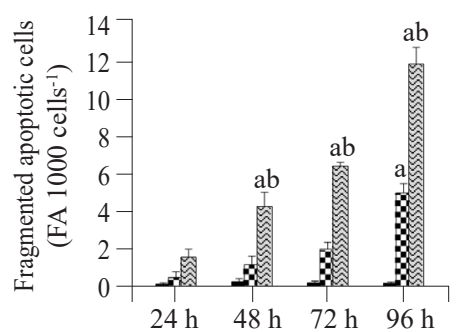

(g)

Duration

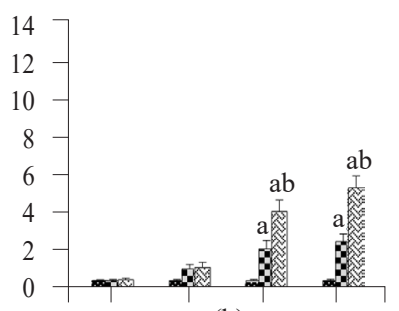

(b)

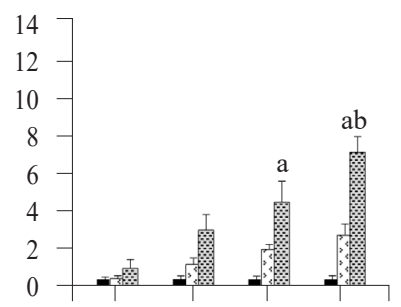

(e)

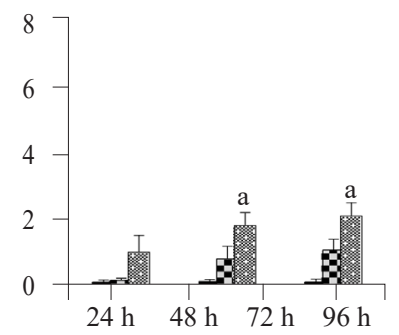

(h)

Duration

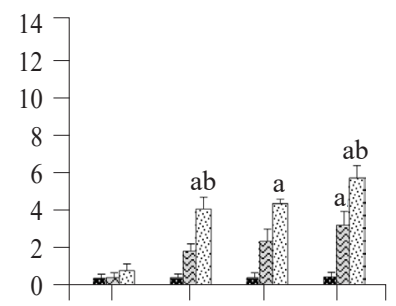

(c)

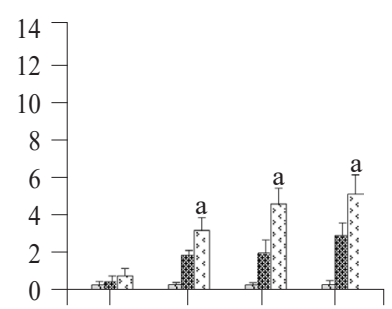

(f)

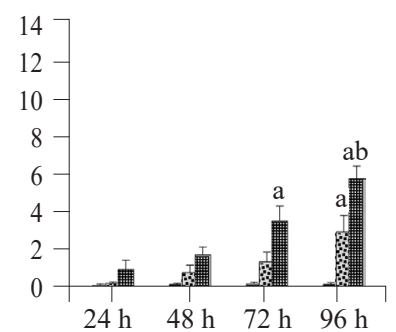

(i)

Duration

표 Control, $0.37 \mathrm{mgl}^{-1}, \ldots 0.62 \mathrm{mgl}^{-1}$

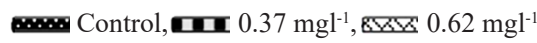

C... Control, $0.37 \mathrm{mgl}^{-1}, \cdots 0.62 \mathrm{mgl}^{-1}$

Fig. 2. Micronuclei and nuclear abnormalities frequency in gill cells (a, d, g), erythrocytes of peripheral blood (b, e, h) and cephalic kidney (c, f, i) of $L$. rohita exposed to $\mathrm{CdCl}_{2}$ at different time intervals. Data are presented as mean $\pm \mathrm{SE}$. $\mathrm{p}<0.05$ is considered to be statistically significant, determined by one way ANOVA followed by Tukey's post-hoc test. Lower case alphabet 'a' indicates significant difference with respect to control and ' $\mathrm{b}$ ' as compared to lower concentration $\left(0.37 \mathrm{mg} \mathrm{l}^{-1}\right)$ of $\mathrm{CdCl}_{2}$.

the micronucleus assay for acute exposures than that of erythrocytes of peripheral blood and cephalic kidney.

\section{Acknowledgements}

Authors are grateful to DST INSPIRE, New Delhi, India for providing senior reaserch fellowship and financial support to Sakshi Verma and to Sultan Fish Seed Farm, Haryana, India for providing fish.

\section{References}

Al-Sabti, K. and Metcalfe, C. D. 1995. Fish micronuclei for assessing genotoxicity in water. Mutat. Res., 343(2-3): 121-135.

Anbumani, S. and Mohankumar, M. N. 2012. Gamma radiation induced micronuclei and erythrocyte cellular abnormalities in the fish Catla catla. Aquat. Toxicol., 122-123: 125-132.

Atli, G. and Canli, M. 2008. Responses of metallothionein and reduced glutathione in a freshwater fish Oreochromis niloticus following metal exposures. Environ. Toxicol. Pharmacol., 25(1): 33-38.
Barsiene, J., Andreikenaite, L., Garnaga, G. and Rybakovas, A 2008. Genotoxic and cytotoxic effects in bivalve mollusks Macoma balthica and Mytilus edulis from the Baltic Sea. Ekologija, 54(1): 44-50.

Barsiene, J., Dedonyte, V., Rybakovas, A., Andreikenaite, L. and Andersen, O. K. 2005. Induction of micronuclei in Atlantic cod (Gadus morhua) and turbot (Scophthalmus maximus) after treatment with bisphenol A, diallyl phthalate and tetrabromodiphenyl ether-47. Ekologija, 4(1): 1-7.

Barsiene. J., Syvokiene, J. and Bjornstad, A. 2006. Induction of micronuclei and other nuclear abnormalities in mussels exposed to bisphenol A, diallyl phthalate and tetrabromodiphenyl ether-47. In: Anderson, O. K., Viarengo, A. and Pampanin, D. M. (Eds.). The stavanger workshop biological effects of environmental pollution (BEEP) in marine coastal ecosystem: the stavanger mesocosm exposure studies, 17-19 October, 2002. Stavanger, Norway. Aquat. Toxicol., 78 (Suppl. 1): S105-S108.

Bolognesi, C., Perrone, E., Roggieri, P., Pampanin, D. M. and Andrea Sciutto, A. 2006. Assessment of micronuclei induction 
in peripheral erythrocytes of fish exposed to xenobiotics under controlled conditions. In: Anderson, O. K., Viarengo, A. and Pampanin, D. M. (Eds.). The stavanger workshop biological effects of environmental pollution (BEEP) in marine coastal ecosystem: the stavanger mesocosm exposure studies, 17-19 October, 2002. Stavanger, Norway. Aquat. Toxicol., 78 (Suppl. 1): S93-S98.

Cavas, T. and Ergene-Gozukara, S. 2003. Micronuclei, nuclear lesions and interphase silver stained nucleolar organizer regions (AgNORs) as cytogenotoxicity indicators in Oreochromis niloticus exposed to textile mill effluent. Mutat. Res., 538(1-2): 81-91.

Cavas, T., Garanko, N. N. and Arkhipchuk, V. V. 2005. Induction of micronuclei and binuclei in blood, gill and liver cells of fishes subchronically exposed to cadmium chloride and copper sulphate. Food Chem. Toxicol., 43(4): 569-574.

COMAPS 1990-1999. Decadal monitoring profile, West Bengal Coast. http://cpcb.nic.in/upload/Newsletters/Newsletters 61 _CADMIUM-An\%20EnvironmentToxicant-March-2007.pdf

Fenech, M., Chang, W. P., Kirsch-Volders, M., Holland, N., Bonassi, S. and Zeiger, E. 2003. HUMN project: detailed description of the scoring criteria for the cytokinesis-block micronucleus assay using isolated human lymphocyte cultures. Mutat. Res., 534 (1-2): 65-75.

Gad, S. C. 2014. Cadmium. In: Wexler, P. (Ed.), Encyclopedia of toxicology. Academia Press, p. 613-616.

Holcik, M. 2002. Do mature red blood cells die by apoptosis? Trends Genet., 18: 121.

Howat, W. J. and Wilson, B. A. 2014. Tissue fixation and the effect of molecular fixatives on downstream staining procedures. Methods, 70(1): 12-19.

IARC 1993. Beryllium, cadmium, mercury and exposures in the glass manufacturing industry. IARC Monogr. Eval. Carcinog. Risks Hum., 58: 1-415.

Jindal, R. and Verma, S. 2015. In vivo genotoxicity and cytotoxicity assessment of cadmium chloride in peripheral erythrocytes of Labeo rohita (Hamilton). Ecotoxicol. Environ. Safe., 118: $1-10$.
Kaur, R. and Dua, A. 2016. Fish liver and gill cells as cytogenotoxic indicators in assessment of water quality. Environ. Sci. Pollut. Res., 23 (18): 18892-18900.

MacGregor, J. T., Wehr, C. M. and Gould, D. H. 1980. Clastogeninduced micronuclei in peripheral blood erythrocytes: the basis of an improved micronucleus test. Environ. Mol. Mutagen., 2(4): 509-514.

Manna, G. K. and Sadhukhan, A. 1986. Use of cells of gill and kidney of tilapia fish in micronucleus test (MNT). Curr. Sci., 55(10): 498-501.

Ozkan, F., Gunduz, S. G., Berkoz, M. and Hunt, A. O. 2011. Induction of micronuclei and other nuclear abnormalities in peripheral erythrocytes of Nile tilapia, Oreochromis niloticus, following exposure to sublethal cadmium doses. Turk. $J$. Zool., 35(4): 585-592.

Rybakovas, A., Barsiene, J. and Lang, T. 2009. Environmental genotoxicity and cytotoxicity in the offshore zones of the Baltic and the North Seas. Mar. Environ. Res., 68(5): 246-256.

Shimizu, N., Itoh, N., Utiyama, H. and Wahl, G. M. 1998. Selective entrapment of extrachromosomally amplified DNA by nuclear budding and micronucleation during S-phase. J. Cell Biol., 140(6): 1307-1320.

Shimizu, N., Shimuara, T. and Tanaka, T. 2000. Selective elimination of acentric double minutes from cancer cells through the extrusion of micronuclei. Mutat. Res., 448(1): 81-90.

Vignardi, C. P., Hasue, F. M., Sartorio, P. V., Cardosa, C. M., Machado, A. S. D., Passos, M. J. A. C. R., Santos, T. C. A., Nucci, J. M., Hewer, T. L. R., Ii-Sei Watanabe, Gomes, V. and Phan, N. V. 2015. Genotoxicity, potential cytotoxicity and cell uptake of titanium dioxide nanoparticles in the marine fish Trachinotus carolinus (Linnaeus, 1766). Aquat. Toxicol., 158: 218-229.

Vincent-Hubert, F., Arini, A. and Gourlay-France, C. 2011. Early genotoxic effects in gill cells and haemocytes of Dreissena polymorpha exposed to cadmium, $\mathrm{B}[\mathrm{a}] \mathrm{P}$ and a combination of B[a]P and Cd. Mutat. Res., 723(1): 26-35.

Waisberg, M., Joseph, P., Hale, B. and Beyersmann, D. 2003. Molecular and cellular mechanisms of cadmium carcinogenesis. Toxicology, 192(2-3): 95-117.

Yadav, K. K. and Trivedi, S. P. 2009. Sublethal exposure of heavy metals induces micronuclei in fish, Channa punctata. Chemosphere, 77: 1495-1500. 